\title{
EVALUASI IMPLEMENTASI PKP DALAM PEMBELAJARAN BIOLOGI DI SMAN KOTA SEMARANG MENGGUNAKAN PENDEKATAN MIXED-METHOD \\ ${ }^{1)}$ Wini Isnaeni, ${ }^{2)}$ Kumaidi \\ ${ }^{2}$ Universitas Negeri Semarang, ${ }^{2}$ Universitas Muhammadiyah Surakarta

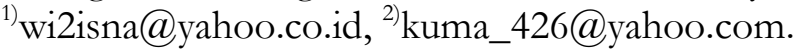

\begin{abstract}
Abstrak
Penelitian ini bertujuan mengevaluasi secara komprehensif tentang implementasi pendekatan keterampilan proses (PKP) dalam pembelajaran biologi di SMAN Kota Semarang, dan mengungkap berbagai faktor pendukung dan penghambatnya. Penelitian ini menggunakan model evaluasi kesenjangan. Data dikumpulkan dengan pendekatan mixed-method, diawali dengan penggunaan metode kuantitatif dilanjutkan dengan metode kualitatif. Data kuantitatif tingkat penggunaan keterampilan proses oleh peserta didik dikumpulkan menggunakan kuesioner. Kuesioner dikembangkan dengan memodifikasi langkah Madaus et al., Claeys et al., dan Wheeler, melalui tahap review literatur, mengkonstruksi instrumen, menetapkan validitas isi dengan cara validasi pakar, dan uji coba lapangan. Data kualitatif tentang proses pembelajaran biologi dan data kualitatif lainnya, diperoleh melalui observasi, pembuatan catatan lapangan, kategorisasi catatan lapangan, dan wawancara mendalam. Seluruh data dianalisis dengan explanatory mixed-method analysis. Hasil penelitian menunjukkan bahwa kualitas implementasi PKP dalam pembelajaran biologi di SMAN kota Semarang belum mencapai kategori baik. Faktor pendukung dan penghambat utamanya adalah tinggi dan rendahnya komitmen guru untuk mengimplementasikan PKP dalam pembelajaran biologi.
\end{abstract}

Kata kunci: evaluasi implementasi kurikulum, pendekatan keterampilan proses, pembelajaran biologi, mixed-method

\section{AN EVALUATION OF THE PSA IMPLEMENTATION IN BIOLOGY TEACHING AT STATE HIGH SCHOOLS IN SEMARANG CITY USING THE MIXED-METHOD APPROACH}

Wiwi Isnaeni, Kumaidi

Universitas Negeri Semarang, Universitas Muhammadiyah Surakarta wi2isna@yahoo.co.id,kuma_426@yahoo.com.

\begin{abstract}
This study aims to evaluate the implementation of the process skill approach (PSA) in the biology teaching at state high schools in Semarang City, and reveal the various supporting factors and the constraints. The study used a discrepancy evaluation model. The data were collected using a mixed-methods approach, initiated with the use of the quantitative method followed by the use the qualitative method. The quantitative data about the level of the process-skill use by the students were collected using questionnaire. The questionnaire was developed by referring to the steps of Madaus et al., Claeys et al., and Wheeler, through reviewing literature, constructing instruments, and determining the content validaty through expert validation, and conducting field trials. The qualitative data about the biology teaching process and the other qualitative data were collected through observation, the preparation of field notes and categorization of field notes, and in depth interview. The whole data were analyzed using the explanatory mixed-method analysis. The result shows that the quality of the implementation of the biology curriculum at state high schools in Semarang City is not in a good category yet. The main supporting factors and the constraints are the the teachers' high and low commitment to implement the PSA in the biology teaching.
\end{abstract}

Keywords: evaluation of curriculum implementation, process skill approach, biologi learning, mixed-method 


\section{Pendahuluan}

Pendekatan keterampilan proses sain (PKP) merupakan pendekatan khas untuk membelajarkan biologi, seperti yang telah dikemukakan dalam kurikulum biologi. Kurikulum adalah seperangkat rencana dan pengaturan mengenai tujuan, isi, bahan pelajaran, sekaligus sebagai pedoman penyelenggaraan kegiatan pembelajaran untuk mencapai tujuan pendidikan tertentu (BSNP, 2006, p.3). Kurikulum yang diimplementasikan, perlu dipantau agar tingkat kesesuaian antara rencana dan pelaksanaannya dapat diketahui (Alfiero et al., 2008, p.13). Evaluasi terhadap implementasi kurikulum juga bermanfaat untuk mengontrol kualitas kurikulum itu.

Perubahan kurikulum di Indonesia sudah dilakukan beberapa kali, namun mutu pendidikan di Indonesia (khususnya untuk bidang sain) masih tetap rendah. Hal ini dapat diketahui dari hasil studi TIMMS dan hasil asesmen PISA, yang menggambarkan performan peserta didik Indonesia yang sangat rendah di tingkat internasional. Hasil studi TIMMS tahun 1999 menunjukkan bahwa tingkat penguasaan IPA oleh anakanak Indonesia pada tingkat internasional menempati urutan ke-32 dari 38 negara peserta (Hayat, 2006, p.1). Hasil asesmen PISA tahun 2009 menunjukkan bahwa performan peserta didik Indonesia (berusia 15 tahun) pada bidang sain menempati urutan ke-57 dari 65 negara peserta (OECD, 2010, p.8).

Hasil asesmen tersebut menggambarkan bahwa perubahan kurikulum di Indonesia dalam kurun waktu 10 tahun terakhir (tahun 1999-2009) ternyata belum dapat menghasilkan lulusan yang mampu bersaing di tingkat internasional. Mengapa perubahan kurikulum selama 10 tahun tersebut belum mampu meningkatkan performa atau penguasaan sain oleh anak Indonesia?

Kurikulum merupakan jantungnya dunia pendidikan (Puskur, 2007, p.1). Perubahan kurikulum dapat dipandang sebagai cara yang tepat untuk meningkatkan mutu pendidikan di Indonesia. Kunci utama untuk mencapai keberhasilan dalam mengupa- yakan peningkatan kualitas program pendidikan ialah penyelenggaraan proses pembelajaran yang berkualitas (Widoyoko, 2008, p.1). Pendapat tersebut sesuai dengan pernyataan Djohar (2003, p.3) bahwa perbaikan kurikulum harus dibarengi dengan perbaikan praksis pembelajaran. Perubahan kurikulum tanpa disertai perubahan praksis pembelajaran tidak akan menghasilkan apa-apa. Uraian tersebut dapat ditegaskan bahwa implementasi kurikulum Biologi harus dilaksanakan dengan menyelenggarakan proses pembelajaran yang optimal, dalam hal ini harus sesuai tuntutan standar proses yang ditetapkan BSNP.

Berkaitan dengan hal itu, upaya meningkatkan kualitas pendidikan harus dimulai dengan meningkatkan kualitas proses pembelajaran. Pembelajaran adalah proses interaksi antara peserta didik, pendidik, dan sumber belajar pada suatu lingkungan belajar (pasal 1 ayat 20 Undang-Undang Sisdiknas Nomor 20 Tahun 2003). Berdasar kepada uraian tersebut maka jelas bahwa proses pembelajaran biologi yang berkualitas merupakan kunci keberhasilan implementasi kurikulum biologi. Oleh karena itu perlu dilakukan evaluasi terhadap implementasi kurikulum biologi, agar kualitas atau efektivitas implementasinya dapat diketahui. Untuk mewujudkan kegiatan pembelajaran yang efektif dan efisien, implementasi kurikulum harus mengacu kepada strandar proses (Permendiknas Nomor 41 Tahun 2007 \& No. 22 tahun 2006)

Proses pembelajaran biologi yang dikehendaki adalah pembelajaran yang sesuai dengan karakteristik sain/biologi dan karakteristik pendidikan sain (Permendiknas Nomor 41 Tahun 2007), yaitu proses pembelajaran aktif berbasis exploring dan inquiring (pembelajaran yang berorientasi kepada eksplorasi dan inkuiri). Pembelajaran berorientasi inkuiri dideskripsikan sebagai proses aktif yang melibatkan berbagai kegiatan seperti observasi, merancang investigasi, juga menggunakan alat untuk mengumpulkan, menganalisis, dan menginterpretasikan data, mengajukan pertanyaan, dan membuat prediksi serta mengkomunikasikan hasil 
(Smith et.al., 2007, p.170). Pembelajaran seperti yang dimaksud secara luas disebut sebagai pembelajaran yang menerapkan pendekatan keterampilan proses.

Keterampilan proses dapat digolongkan menjadi 2, yaitu keterampilan dasar/ basic skills dan keterampilan terintegrasi/ integrated skills (Arena, 1996 dalam Martin et.al., 2005, pp.17-20). Keterampilan dasar meliputi keterampilan observasi, klasifikasi, komunikasi, pengukuran, estimasi, prediksi dan interferensi. Keterampilan terintegrasi/ terpadu meliputi keterampilan untuk mengidentifikasi variabel, mengontrol variabel, membuat definisi operasional, membuat hipotesis, melakukan eksperimen, membuat grafik, menginterpretasikan data, pemodelan, dan melakukan penyelidikan.
Melakukan penyelidikan/investigasi berkaitan dengan perolehan produk ilmu baru. Pola saling hubungan antara kegiatan investigasi (terhadap gejala/fenomena di alam), proses ilmiah, dan perolehan produk ilmiah dinyatakan oleh Carin \& Sund (1989, p.6) seperti pada Gambar 1. Berdasarkan kepada Gambar 1 dapat dinyatakan bahwa pelaksanaan pembelajaran biologi dengan menekankan penggunaan metode ilmiah atau pendekatan keterampilan proses (PKP) akan memberi peluang kepada peserta didik untuk mengembangkan ilmu yang dimilikinya, dengan menghasilkan produk baru. Oleh karena itu, pengembangan keterampilan proses sain pada peserta didik harus benar-benar dapat dilaksanakan dalam pembelajaran biologi.

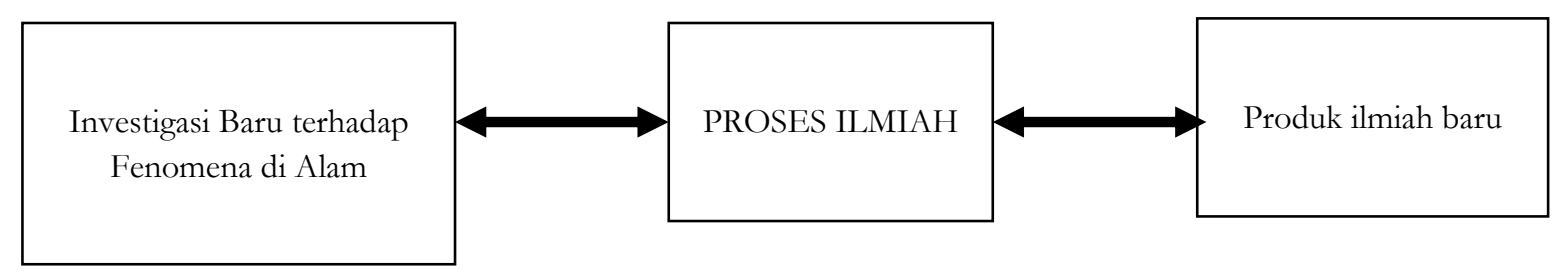

Gambar 1. Gambaran Ringkas tentang Saling Hubungan antara Investigasi Gejala, Proses Ilmiah, dan Perolehan Produk Ilmiah (Dimodifikasi dari Carin \& Sund, 1989, p.6).

Evaluasi dapat menjadi upaya untuk memperbaiki bagian program yang diselenggarakan dengan kurang baik (Worthen \& Sanders, 1981). Evaluasi juga menggunakan metode penilaian yang memerlukan informasi/deskripsi kuantitatif (misalnya skor tes hasil pengukuran) dan informasi/deskripsi kualitatif (misalnya catatan tentang perilaku peserta didik dan pendidik/guru dalam pembelajaran; Setiadi dkk, 2006, p.69). Evaluasi mengandung dua pengertian, yaitu deskripsi kualitatif dari perilaku peserta didik dan deskripsi kuantitatif dari hasil pengukuran (misalnya skor tes). Jadi, evaluasi mencakup pengukuran dan bersifat lebih komprehensif. Hal serupa juga dikemukakan oleh Abd. Rahman A. Ghani (dalam Setiadi dkk., 2006, p.69) yang menjelaskan bahwa evaluasi adalah metode penilaian yang tidak hanya tergantung kepada pengukuran.
Mengingat bahwa evaluasi memerlukan informasi kuantitatif dan kualitatif sekaligus maka dalam evaluasi perlu diterapkan gabungan antara metode kuantitatif dan kualitatif sekaligus (menggunakan pendekatan mixed-method). Penggunaan metode evaluasi kuantitatif dalam proses evaluasi (misalnya dalam evaluasi kurikulum) diyakini mampu menyajikan berbagai data yang terkait dengan indikator yang dapat menggambarkan tingkat keterlaksanaan kurikulum yang sedang berlaku, namun tidak mampu menjelaskan berbagai hal yang terjadi di balik suatu gejala/peristiwa, misalnya alasan yang melatarbelakangi seorang guru dalam memilih strategi pembelajaran tertentu. Hal yang tidak terungkap tersebut merupakan informasi kualitatif, yang berperan sangat penting dalam menjelaskan informasi kuantitatif. Hal ini sesuai dengan pernyataan Brannen (2005, p.85) yang mengemukakan 
bahwa penelitian kualitatif dapat membantu penelitian kuantitatif, antara lain dengan memberikan informasi dasar tentang konteks dan subjek. Penelitian/data kualitatif juga dapat membantu interpretasi hubungan antar variabel, dan juga dapat digunakan untuk menjelaskan faktor-faktor yang mendasari hubungan yang terbangun. Dengan demikian, maka jelas bahwa dalam evaluasi, tidak terkecuali dalam evaluasi implementasi PKP dalam pembelajaran biologi, sangat diperlukan informasi kuantitatif dan kualitatif bersama-sama (menggunakan pendekatan mixed-method).

Berdasar uraian tersebut maka penelitian ini bertujuan untuk: (1) mengungkap sejauh mana kualitas implementasi PKP dalam pembelajaran biologi di SMA Negeri Kota Semarang yang dikaji dengan pendekatan mixed-method; (2) mengungkap berbagai faktor pendukung dan penghambat untuk mengimplementasikan PKP dalam pembelajaran biologi. Manfaat dari penelitian ini ialah memberikan informasi komprehensif kepada sekolah dan masyarakat tentang kualitas pembelajaran biologi yang diselenggarakan di SMA Negeri Kota Semarang, serta berbagai faktor pendukung dan penghambatnya.

\section{Metode Penelitian}

Penelitian ini menggunakan model evaluasi kesenjangan (discprepancy) (Madaus et al., 1986, p.79; Steinmetz, 2000, p.143; Stufflebeam et al., 2002, p.127; Arikunto \& Jabar, 2004, p.31), dan menggunakan metode gabungan antara metode kuantitatif dan metode kualitatif atau pendekatan mixed-method, tepatnya explanatory mixedmethod design (Creswell, 2008, p.552).

Penelitian dilaksanakan di SMA Negeri Kota Semarang, pada bulan September 2012 sampai dengan Januari 2013, yaitu pada SMAN AA, dan SMAN AB, SMAN AC, SMAN AD, SMAN AE dan SMA AF di Semarang (nama-nama SMA disamarkan).

Subjek penelitian ini ialah guru dan peserta didik yang terlibat dalam proses pembelajaran Biologi yang diselenggarakan pada SMA negeri di kota Semarang yang dipilih dengan pertimbangan tertentu. Objek penelitian ini adalah aktivitas peserta didik dan guru, serta proses pembelajaran biologi yang dipilih untuk diobservasi dengan pertimbangan tertentu.

Langkah pertama penelitian ini ialah mengembangkan kuesioner. Kuesioner dikembangkan dengan memodifikasi langkah yang dilakukan Madaus et al. (1986, p.83), Claeys et al. (2012, p.577), dan Wheeler (2012, p.43), melalui tahap review literatur, mengkonstruksi instrumen, membuktikan validitas isi melalui kesepakan ahli, dan uji coba lapangan. Uji coba lapangan dilakukan dengan melibatkan jumlah peserta didik yang makin meningkat dari uji coba pertama, kedua, dan ketiga. Data hasil uji coba lapangan dianalisis menggunakan exploratory factor analysis (EFA), sampai diperoleh kuesioner final yang layak. Dari hasil uji coba yang ketiga dapat diperoleh kuesioner yang valid dan reliabel. Berdasarkan hasil EFA diketahui dari nilai total kumulatif varian $\geq 50 \%$, dan nilai komponen matrik rotasi per butir $\geq 0,3$. Kisaran nilai komponen matrik rotasi per butir untuk keterampilan dasar adalah antara 0,493 sampai 0,904, sedangkan untuk keterampilan terpadu kisarannya antara 0,476-0,837. Reliabilitas instrumen diketahui dari nilai $\alpha$ Cronbach untuk dimensi keterampilan dasar dan terpadu masing-masing 0,670 dan 0,775. Instrumen tersebut selanjutnya digunakan sebagai alat pengumpul data dalam penelitian ini.

Penelitian diawali dengan pengumpulan dan analisis data kuantitatif, dilanjutkan dengan pengumpulan dan analisis data kualitatif. Hasilnya digunakan untuk memberikan penjelasan/eksplanasi lebih lanjut mengenai fenomena yang belum dapat dijelaskan oleh hasil penelitian kuantitatif.

Jenis data, kategori data, teknik pengumpulan data, instrumen yang digunakan, dan sumber data disajikan pada Tabel 1. Data yang dikumpulkan mencakup data kuantitatif dan data kualitatif. Data kuantitatif berupa kadar inkuiri atau tingkat implementasi keterampilan proses dikumpulkan menggunakan kuesioner. Data ini 
menunjukkan tingkat penggunaan keterampilan dasar dan keterampilan terpadu oleh peserta didik. Data kualitatif tentang pelaksanaan proses pembelajaran biologi dikumpulkan melalui proses observasi, pembuatan catatan lapangan dan kategorisasi catatan lapangan, serta wawancara mendalam dengan responden (guru dan peserta didik).

Catatan lapangan adalah dokumentasi tertulis tentang berbagai peristiwa yang ter- jadi pada proses pembelajaran biologi, diperoleh dengan cara mengobservasi proses pembelajaran biologi yang dilaksanakan oleh para guru yang dipilih dengan pertimbangan tertentu (secara purposif). Pembuatan catatan lapangan dilakukan selama penyelenggaraan proses pembelajaran biologi untuk kompetensi dasar atau materi ajar tertentu.

Tabel 1. Jenis dan Kategori Data/Informasi yang Dikumpulkan, Teknik Pengumpulan Data, Instrumen, dan Sumber Data pada Penelitian Ini

\begin{tabular}{|c|c|c|c|c|}
\hline No & Jenis dan kategori data & $\begin{array}{l}\text { Teknik dan metode } \\
\text { pengumpulan data }\end{array}$ & Instrumen & Sumber data \\
\hline 1 & $\begin{array}{l}\text { Tingkat implementasi PKP dalam } \\
\text { pembelajaran biologi selama } 1 \\
\text { semester-data kuantitatif }\end{array}$ & Kuesioner (kuantitatif) & Kuesioner & $\begin{array}{l}\text { Peserta didik } \\
\text { kelas XI IPA }\end{array}$ \\
\hline 2 & $\begin{array}{l}\text { Proses pembelajaran biologi } \\
\text { untuk KD tertentu - data } \\
\text { kualitatif }\end{array}$ & Observasi (kualitatif) & $\begin{array}{l}\text { Lembar untuk } \\
\text { catatan } \\
\text { lapangan }\end{array}$ & $\begin{array}{l}\text { Proses pembel- } \\
\text { ajaran biologi }\end{array}$ \\
\hline 3 & $\begin{array}{l}\text { Tingkat implementasi PKP dalam } \\
\text { PBM biologi pada KD } \\
\text { terobservasi didasarkan catatan } \\
\text { lapangan - data kuantifikasi }\end{array}$ & $\begin{array}{l}\text { Kategorisasi catatan } \\
\text { lapangan (kuantifikasi) }\end{array}$ & $\begin{array}{l}\text { Lembar } \\
\text { kategorisasi }\end{array}$ & $\begin{array}{l}\text { Catatan } \\
\text { lapangan }\end{array}$ \\
\hline \multirow[t]{2}{*}{4} & \multirow{2}{*}{$\begin{array}{l}\text { Tanggapan guru PBM biologi } \\
\text { yang dilaksanakan (untuk KD } \\
\text { tertentu) - data kualitatif dan } \\
\text { kuantifikasi }\end{array}$} & Wawancara (kualitatif) & $\begin{array}{l}\text { Panduan } \\
\text { wawancara }\end{array}$ & $\begin{array}{l}\text { Guru biologi } \\
\text { terpilih }\end{array}$ \\
\hline & & $\begin{array}{l}\text { kuesioner (kuantitatif/ } \\
\text { kuantifikasi) }\end{array}$ & kuesioner & $\begin{array}{l}\text { Guru anggota } \\
\text { MGMP biologi }\end{array}$ \\
\hline
\end{tabular}

Seluruh data yang diperoleh dianalisis dengan explanatory mixed-method analysis, (Creswell, 2008, p.557), diawali dengan analisis data kuantitatif menggunakan teknik kuantitatif deskriptif, dilanjutkan dengan eksplanasi dan elaborasi terhadap hasil temuan kuantitatif tersebut menggunakan kumpulan data kualitatif yang telah diperoleh dengan teknik-teknik kualitatif.

\section{Hasil Penelitian dan Pembahasan}

Hasil penelitian ini terdiri dari dua kategori, yaitu hasil kuantitatif dan hasil kualitatif. Hasil penelitian kuantitatif pada penelitian ini menginformasikan tingkat implementasi PKP pada berbagai SMA negeri di Kota Semarang. Data ini menggambarkan tingkat penggunaan keterampilan dasar dan keterampilan terpadu yang digunakan pe-serta didik selama belajar biologi. Data kuantitatif menunjukkan bahwa tingkat implementasi PKP dalam pembelajaran biologi di kelas XI IPA semester gasal adalah $72 \%$ (disajikan pada Tabel 2). Dalam hal ini, peserta didik menggunakan keterampilan dasar masing-masing $(71: 2) \%=35,5 \%$ dan keterampilan terpadu sebesar $(73: 2) \%=$ $36,5 \%$. 
Tabel 2. Tingkat Implementasi PKP dalam Proses Pembelajaran Biologi pada Berbagai SMAN di Kota Semarang pada Kelas XI Semester Gasal.

\begin{tabular}{|c|c|c|c|c|c|c|c|}
\hline \multirow[t]{2}{*}{ Dimensi dan Sub Dimensi } & \multicolumn{6}{|c|}{$\begin{array}{c}\text { Persentase Tingkat implementasi PKP dalam } \\
\text { pembelajaran Biologi yang diselenggarakan di SMA }\end{array}$} & \multirow{2}{*}{$\begin{array}{l}\text { Rerata } \\
\text { dalam } \\
\text { persen }\end{array}$} \\
\hline & $\mathrm{AD}^{*}$ & $\mathrm{AE}^{*}$ & $\mathrm{AA}^{*}$ & $\mathrm{AB} *$ & $\mathrm{AC}^{*}$ & $\mathrm{AF}^{*}$ & \\
\hline \multicolumn{8}{|l|}{ Keterampilan Dasar (Pildas) } \\
\hline Observasi & 55 & 73 & 40 & 74 & 75 & 100 & 71 \\
\hline Mengukur & 41 & 89 & 65 & 55 & 57 & 75 & 62 \\
\hline Mengklasifikasikan & 68 & 95 & 72 & 91 & 96 & 100 & 89 \\
\hline Mengkomunikasikan & 90 & 57 & 82 & 85 & 86 & 68 & 80 \\
\hline Memperkirakan & 31 & 72 & 58 & 63 & 45 & 61 & 56 \\
\hline Menyimpulkan & 54 & 85 & 70 & 83 & 85 & 33 & 72 \\
\hline Penggunaan Pildas/SMA & 59 & 79 & 65 & 75 & 74 & 73 & $71 * *$ \\
\hline \multicolumn{8}{|l|}{ Keterampilan Terpadu (Pilter) } \\
\hline Merencanakan penelit. & 58 & 85 & 78 & 81 & 79 & 89 & 79 \\
\hline Merumuskan hipotesis & 57 & 93 & 72 & 87 & 82 & 100 & 82 \\
\hline $\begin{array}{l}\text { Melakukan } \\
\text { penelitian/penyelidikan }\end{array}$ & 39 & 99 & 84 & 95 & 93 & 100 & 74 \\
\hline Menginterpretasikan data & 51 & 98 & 94 & 91 & 90 & 100 & 89 \\
\hline $\begin{array}{l}\text { Mempresentasikan hasil } \\
\text { penelitian/hasil kajian teoretik }\end{array}$ & 81 & 42 & 49 & 84 & 59 & 55 & 64 \\
\hline Penggunaan Pilter/SMA & 57 & 84 & 75 & 88 & 80 & 89 & $73 * *$ \\
\hline $\begin{array}{l}\text { Rerata persen penggunaan } \\
\text { keterampilan proses per SMA *** }\end{array}$ & 58 & 81 & 70 & 81 & 78 & 81 & \\
\hline $\begin{array}{l}\text { Rerata persen tingkat } \\
\text { implementasi PKP **** }\end{array}$ & \multicolumn{6}{|c|}{$(71+73): 2=72 \%$} & \\
\hline
\end{tabular}

\section{Keterangan:}

* : AD: SMAN AD Smg; AE: SMAN AE Smg. AA: SMAN AA Smg; AB: SMAN AB Smg; AC: SMAN AC Smg. AF: SMA AF Smg

** : Rerata persen penggunaan keterampilan dasar atau keterampilan terpadu dalam pembelajaran biologi untuk seluruh sekolah yang diobservasi.

*** : Rerata persen penggunaan keterampilan proses sain dalam pembelajaran biologi untuk seluruh sekolah yang diobservasi.

**** : Tingkat implementasi PKP 50-70\%: cukup; tingkat implementasi $>70 \%$ : baik.

Berdasarkan data pada Tabel 2 (baris kedua dari bawah), dapat diketahui bahwa tingkat implementasi PKP di SMA Negeri Kota Semarang relatif bervariasi. Mengacu kepada keterangan tentang kategori tingkat implementasi PKP yang disajikan pada bagian bawah Tabel 2, dapat diketahui bahwa tingkat implementasi PKP dalam pembelajaran biologi pada SMA Negeri di Kota Semarang dapat dikelompokkan menjadi dua kategori, yaitu kategori cukup dan baik. Sekolah yang menunjukkan tingkat implementasi PKP paling rendah ialah SMA Negeri AD (58\%), diikuti oleh SMA Negeri AA yang tingkat implementasinya mencapai
$70 \%$. Kedua sekolah tersebut menunjukkan tingkat implementasi PKP sebesar $\leq 70 \%$, sehingga dapat dinyatakan mencapai kategori cukup. Mengingat bahwa rata-rata tingkat implementasi PKP di Kota Semarang adalah $72 \%$ maka dapat dinyatakan bahwa tingkat implementasi PKP dalam pembelajaran biologi di SMA Negeri Kota Semarang secara kuantitatif termasuk kategori baik.

Hasil temuan kuantitatif tersebut perlu dijelaskan dan dielaborasi antara lain menggunakan data kualitatif berupa catatan lapangan. Gambaran tentang isi catatan lapangan secara umum disajikan pada Tabel 3. 
Tabel 3. Gambaran Umum Isi Catatan Lapangan Hasil Observasi terhadap Proses Pembelajaran Biologi yang Diselenggarakan di Kelas XI IPA pada Semester Gasal pada SMA Negeri di Kota Semarang

\begin{tabular}{|c|c|c|}
\hline No & $\begin{array}{l}\text { Aspek yang } \\
\text { diobservasi }\end{array}$ & Hasil Observasi \\
\hline 1. & $\begin{array}{l}\text { Pelaksanaan } \\
\text { pembelajaran biologi } \\
\text { secara umum }\end{array}$ & $\begin{array}{l}\text { Kegiatan pembelajaran biologi di antara sekolah yang satu dan yang lain sangat } \\
\text { bervariasi, namun pada umumnya masih kurang mencerminkan adanya kegiatan } \\
\text { yang melibatkan peserta didik dalam penggunaan keterampilan proses sain, } \\
\text { terutama sekali dalam hal penggunaan keterampilan terpadu. Jenis keterampilan } \\
\text { dasar yang digunakan peserta didik relatif masih sangat terbatas. Kegiatan } \\
\text { pembelajaran biologi masih didominasi oleh aktivitas komunikasi } \\
\text { (mengkomunikasikan), baik dalam bentuk komunikasi lisan maupun komunikasi } \\
\text { tertulis. Kegiatan observasi objek studi berupa benda asli masih sangat terbatas. }\end{array}$ \\
\hline 2. & $\begin{array}{l}\text { Peran guru dalam } \\
\text { pembelajaran }\end{array}$ & $\begin{array}{l}\text { Peran guru dalam pembelajaran paling dominan sebagai narasumber utama. } \\
\text { Dalam diskusi/presentasi, guru berperan sebagai fasilitator, narasumber, dan } \\
\text { evaluator, juga sebagai konsultan. Dalam kegiatan praktikum, guru memainkan } \\
\text { sangat banyak peran, yaitu sebagai fasilitator, pembimbing, narasumber, } \\
\text { laboran/teknisi laboratorium. Selama observasi, ada guru yang tidak } \\
\text { menyelenggarakan praktikum sekalipun, dan dalam keadaan demikian, peserta } \\
\text { didik menjadi pasif, dengan aktivitas mendengar dan mencatat. }\end{array}$ \\
\hline 3. & $\begin{array}{l}\text { Metode/strategi } \\
\text { pembelajaran yang } \\
\text { digunakan }\end{array}$ & $\begin{array}{l}\text { Penggunaan metode ilmiah (keterampilan dasar dan terpadu) yang cukup } \\
\text { menonjol, ditemukan pada sekolah yang berlokasi di daerah marginal. }\end{array}$ \\
\hline 4. & $\begin{array}{l}\text { Objek studi yang } \\
\text { diobservasi }\end{array}$ & $\begin{array}{l}\text { Objek studi yang diobservasi kebanyakan berupa objek yang dihadirkan kedalam } \\
\text { kelas dengan bantuan IT, atau berupa objek tiruan/torso/model, karena materi } \\
\text { yang dikaji selama observasi, adalah tentang sistem gerak, sirkulasi, dan } \\
\text { pencernaan makanan. }\end{array}$ \\
\hline 5. & $\begin{array}{l}\text { Keterlibatan peserta } \\
\text { didik dalam } \\
\text { pembelajaran }\end{array}$ & $\begin{array}{l}\text { Dalam kegiatan praktikum peserta didik melakukan pengamatan susunan otot } \\
\text { dan rangka, pengujian darah (uji kecepatan pembekuan darah dan atau uji } \\
\text { golongan darah), serta uji kandungan zat dalam bahan makanan, dan memnulis } \\
\text { laporan praktikum. Diskusi (kelas/kelompok), dan presentasi lisan. }\end{array}$ \\
\hline
\end{tabular}

Berdasarkan data pada Tabel 3 dapat diperoleh informasi bahwa kegiatan pembelajaran biologi di SMA negeri Kota Semarang masih didominasi oleh praktik pembelajaran yang berorientasi materi (pembelajaran tekstual). Dalam kegiatan pembelajaran yang dimaksud, guru lebih banyak berperan sebagai narasumber utama. Kegiatan pembelajaran biologi masih didominasi oleh aktivitas komunikasi (mengkomunikasikan), baik dalam bentuk komunikasi lisan maupun komunikasi tertulis, sementara kegiatan observasi objek studi berupa benda asli masih sangat terbatas.

Hasil penelitian kualitatif lainnya ialah hasil wawancara dengan guru mata pelajaran biologi, yang menginformasikan persepsi mereka mengenai implementasi PKP dalam pembelajaran biologi. Hasil wawancara memberikan informasi bahwa guru tidak dapat melaksanakan kegiatan pembelajaran biologi yang sepenuhnya sesuai dengan rencana (yang tertulis dalam RPP). Dalam hal ini guru memperkirakan tingkat keterlaksanaan rencana yang mereka buat secara bervariasi, ada yang memperkirakan sekitar $50-75 \%$ (berarti nilai tengahnya adalah $62,5 \%$ ), ada yang memperkirakan $75 \%$, dan ada juga yang memperkirakan 90\%. Jika diambil titik tengahnya dan dirata-ratakan maka rerata tingkat implementasi PKP dalam pembelajaran biologi menurut perkiraan guru adalah $(62,5+75+90): 3=79 \%$. Angka $79 \%$ ini tidak terlalu jauh berbeda dari tingkat implementasi PKP yang tercantum dalam Tabel 3, sebesar 72\%. Apabila keduanya dirata-ratakan maka diperoleh angka $75 \%$. 
Keterlaksanaan implementasi PKP dalam pembelajaran biologi baik sebesar $72 \%$ maupun $75 \%$ menunjukkan bahwa PKP tidak diimplementasikan secara maksimal. Hal ini juga memberikan gambaran proses pembelajaran biologi tidak diselenggarakan secara maksimal. Padahal proses pembelajaran yang berkualitas merupakan kunci utama dalam upaya peningkatan kualitas berbagai program pendidikan (Widoyoko, 2008, p.1). Implementasi PKP yang tidak maksimal dalam pembelajaran biologi juga menggambarkan kurang adanya perbaikan praksis pembelajaran. Sesuai dengan pendapat Djohar (2003, p.3) keadaan semacam itu menyebabkan tidak diperolehnya hasil apapun dari perubahan kurikulum yang dilakukan. Hal itu juga menggambarkan praktik pembelajaran yang tidak sesuai dengan standar proses seperti yang ditetapkan dalam Permendiknas No. 41 Tahun 2007 dan No. 22 Tahun 2006).

Ketidakmaksimalan implementasi PKP dalam pembelajaran biologi disebabkan oleh beberapa alasan, seperti yang dikemukakan para guru berikut ini.

... Tugas guru yang terlalu padat, dengan kewajiban mengajar 24 jam per minggu, di luar tugas tambahan lainnya seperti menjadi wali kelas, pembina kegiatan tertentu dan lain-lain. Hal lain yang menjadi kendala untuk menyelenggara-kan pembelajaran dengan menerapkan PKP ialah banyaknya materi yang harus disampaikan. Kadang guru merasa seperti "dituntut" untuk menyelesaikan materi pada batas waktu tertentu. Jika dilaksanakan praktikum, akan perlu waktu lebih banyak lagi, maka pelaksanaan praktikum dibatasi ...

... Keterlaksanaannya paling-paling sekitar 75\%. Jujur saja, "penjejalan materi" masih berlaku di sekolah ini. Pokoknya materi harus terselesaikan. Kalau dipikir-pikir, dalam KTSP seharusnya tidak perlu ada ujian nasional untuk menentukan kelulusan peserta didik, tetapi cukup dengan ujian sekolab saja. Namun karena masib ada UN (Ujian Nasional), penerapan pendekatan keterampilan proses ya terpaksa diabaikan. Bagaimanapun juga, selama ada UN penyampaian materi harus benar-benar selesai (terselesaikan semua). Jadi, banyak sedikit, UN itu "mengganggu" penerapan pendekatan keterampilan proses sain dalam pembelajaran biologi...

...Faktor penghambat yang utama ya UN. Di satu sisi, UN memang mampu menyemangati guru, peserta didik, maupun orang tua untuk mencapai tingkat yang lebih baik. Saya setuju kalau UN memang tetap diperlukan untuk menyamakan perkembangan peserta didik di suatu sekolah dengan perkembangan peserta didik di sekolah lain... (peneliti: maksudnya, supaya perkembangan atau kemajuan belajar peserta didik diberbagai sekolah dapat disejajarkan).

Beberapa jawaban guru seperti tersebut, tampak bahwa pembelajaran biologi yang diselenggarakan di SMA negeri Kota Semarang masih berorientasi materi atau bersifat tekstual. Pembelajaran tekstual sebenarnya tidak sesuai dengan karakteristik biologi dan karakteristik pembelajaran biologi. Karakteristik pendidikan sain (termasuk biologi) yaitu pembelajaran aktif berbasis exploring dan inquiring (berorientasi eksplorasi dan inkuiri; Permendiknas No. 41 tahun 2007). Meskipun demikian, sebagian besar responden berpendapat bahwa mengkaji materi secara klasikal merupakan hal yang penting, karena materi biologi sangat banyak. Dalam keadaan demikian, guru berpendapat bahwa mengkaji materi hingga tuntas adalah hal yang lebih penting daripada mengimplementasikan PKP. Hal ini dipilih untuk dilakukan guru biologi dengan tujuan agar peserta didik memperoleh kesempatan lebih baik dalam mempersiapkan diri menghadapi UN.

Apabila dikaji secara lebih seksama, sikap guru seperti tersebut pada dasarnya memperlihatkan adanya rasa khawatir pada guru, kalau peserta didik tidak melakukan persiapan diri dengan baik dalam menghadapi UN. Dengan demikian, maka dapat dinyatakan bahwa UN sebenarnya bukan faktor penghambat implementasi PKP dalam pembelajaran biologi. Faktor penghambat yang sebenarnya adalah adanya rasa khawatir pada guru (sebagian guru) dalam 
menghadapi UN. Pendapat peneliti ini didukung oleh pernyataan responden yang tidak ingin terjebak dalam pembelajaran tekstual dan tak perlu khawatir dalam menghadapi UN seperti berikut ini.

...Saya tidak mau terjebak pada proses pembelajaran tekstual. Yang terpenting, pembelajaran dengan PKP harus tetap jalan (terselenggara) meskipun materi ajar tidak dapat disampaikan semuanya. Saya tidak perlu mengkhawatirkan bal itu (peneliti: UN), karena nyatanya peserta didik tetap dapat mengerjakan soal-soal UN dengan baik (peneliti: maksudnya, peserta didik tetap dapat memperoleh nilai UN yang tinggi). Saya tidak peduli UN, karena UN banya untuk peserta didik kelas XII, dan sudah ada media tersendiri untuk mempersiapkan mereka. Tetapi saya tabu, teman-teman pengampu mata pelajaran lain yang tampak masib sangat dipengarubi UN dalam menyelenggarakan pembelajaran...
Berdasar kepada uraian di atas maka dapat dinyatakan bahwa yang menjadi faktor penghambat dalam implementasi PKP dalam pembelajaran biologi mencakup beberapa hal, antara lain ialah padatnya tugas guru, banyaknya materi biologi, dan adanya rasa khawatir pada sebagian besar guru dalam menghadapi UN. Jadi, yang mernjadi penghambat dalam hal ini bukanlah UN.

Gambaran tentang implementasi PKP dalam pembelajaran biologi di SMA negeri kota Semarang juga dapat diketahui dari hasil katergorisasi catatan lapangan. Memperhatikan prosedur pengumpulan data yang dilakukan, data tingkat implementasi PKP (kadar inkuiri) hasil kategorisasi catatan lapangan ini dikelompokkan sebagai data kuantifikasi. Data kuantifikasi tingkat implementasi PKP dalam pembelqajaran biologi disajikan pada Tabel 4 (kolom ke-3 dan ke-4) yang menunjukkan tingkat penggunaan keterampilan dasar dan keterampilan terpadu oleh peserta didik.

Tabel 4. Proporsi Keterampilan Proses Sain yang Digunakan Peserta Didik dalam Belajar Biologi di Kelas XI IPA Semester Gasal di Beberapa SMA Negeri Kota Semarang, pada Materi ajar/KD Tertentu

\begin{tabular}{|c|c|c|c|}
\hline \multirow[b]{2}{*}{ Jenis keterampilan yang digunakan } & \multicolumn{3}{|c|}{$\begin{array}{l}\text { Proporsi penggunaan ketrampilan dasar dan terpadu oleh } \\
\text { peserta didik }\end{array}$} \\
\hline & Frekuensi $*$ & $\begin{array}{c}\text { Keterlaksanaan } \\
\text { kegiatan (I) dalam } \\
\text { persen }\end{array}$ & $\begin{array}{c}\text { Keterlaksanaan riil } \\
(0,72 \mathrm{x} \mathrm{I}) * * * \\
\text { dalam persen }\end{array}$ \\
\hline \multicolumn{4}{|l|}{ Keterampilan Dasar } \\
\hline - Observasi & 77 & $12.5^{* *}$ & $9,0 * * * *$ \\
\hline - Mengukur & 6 & 1.0 & 0,7 \\
\hline - Mengklasifikasikan & 15 & 2.4 & 1,7 \\
\hline - Mengkomunikasikan & 333 & 54.2 & 39,0 \\
\hline - Memperkirakan & 41 & 6.7 & 4,8 \\
\hline - Menyimpulkan & 25 & 4.1 & 3,0 \\
\hline Tingkat Implementasi & & 81 & 58 \\
\hline \multicolumn{4}{|l|}{ Keterampilan Terpadu } \\
\hline - Merencanakan penelitian & 1 & 0.2 & 0,1 \\
\hline - Merumuskan hipotesis & 49 & 7.5 & 5,4 \\
\hline - Melakukan penelitian/Penyelidikan & 32 & 5.2 & 3,7 \\
\hline - Menginterpretasikan data & 28 & 4.6 & 3,3 \\
\hline $\begin{array}{l}\text { - Mempresentasikan hasil } \\
\text { penelitian/hsl kajian teoretik }\end{array}$ & 10 & 1.6 & 1,2 \\
\hline Tingkat implementasi Pil-Ter & & 19 & 14 \\
\hline
\end{tabular}

\section{Keterangan:}

* : Total kegiatan ada 615 kegiatan;

** $:$ Contoh cara menghitung $=(77 / 615) \times 100 \%=12,5 \%$

*** : Kegiatan yang terlaksana dikalikan dengan 0,72 atau $72 \%$ dari yang dilaksanakan.

**** : Keterlaksanaan riil untuk keterampilan mengukur $=12.5 \times 0,72=9,0 \%$ 
Data pada Tabel 4 kolom ke-3 menunjukkan adanya ketidak-seimbangan antara tingkat penggunaan keterampilan dasar dan keterampilan terpadu. Dalam hal ini, tingkat penggunaan keterampilan dasar tampak terlalu dominan, terutama sekali pada keterampilan komunikasi. Mengingat bahwa keterampilan proses terdiri atas keterampilan dasar/basic skills dan keterampilan terpadu (terintegrasi)/integrated skills (Arena, 1996 dalam Martin et.al., 2005, pp.17-20), seharusnya semua jenis keterampilan dapat dikembangkan secara seimbang, bukan didominasi oleh penggunaan keterampilan komunikasi seperti yang ditemukan pada penelitian ini.

Data tentang tanggapan guru mengenai proses pembelajaran biologi diselenggarakan di SMA Negeri Kota Semarang diperoleh dari para guru biologi setelah selesai melaksanakan pembelajaran selama satu semester penuh. Dari mereka, diperoleh berbagai informasi antara lain sebagai berikut. (1) guru biologi di SMAN Kota Semarang sudah berusaha mengimplementasikan PKP dalam pembelajaran, namun tingkat implementasi yang dilaksanakan ternyata berbeda-beda; (2) sebagian besar responden/guru biologi sudah menggunakan alat peraga/media yang cukup bervariasi. Media yang dimaksud mencakup papan tulis, komputer/laptop dengan LCDnya, gambar/model atau makhluk hidup yang sesungguhnya, LKS dan LDS; (3) para guru sudah memanfaatkan kemajuan teknologi komputer sebagai media.

Untuk menjelaskan lebih lanjut tentang gambaran riil proses implementasi PKP dalam pembelajaran biologi, diperlukan informasi tentang proses pembelajaran yang dilaksanakan guru yang diperoleh melalui observasi, yang merupakan data kualitatif. Penggunaan data kuantitatif dan kualitatif pada penelitian ini sesuai dengan pendapat Abd. Rahman A. Ghani (dalam Setiadi dkk., 2010, p.69) yang mengemukakan bahwa evaluasi merupakan metode penilaian yang melibatkan dua hal, yaitu deskripsi kualitatif dari perilaku peserta didik dan deskripsi kuantitatif dari hasil pengukuran (misalnya skor tes).

Dalam penelitian evaluasi, penelitian kualitatif dapat membantu penelitian kuantitatif karena informasi kualitatif berperan sangat penting dalam menjelaskan informasi kuantitatif (Brannen, 2005, p.85). Penelitian atau data kualitatif dapat membantu interpretasi hubungan antar variabel, dan juga dapat digunakan untuk menjelaskan faktorfaktor yang mendasari hubungan yang terbangun.

Dari catatan lapangan dan pengamatan terhadap kegiatan yang dilakukan peserta didik selama belajar biologi dapat diketahui bahwa sebagian besar dari kegiatan observasi objek studi yang mereka lakukan ternyata bukan kegiatan mengamati objek/ alam, namun lebih banyak mengamati struktur/gambar tertentu yang berasal dari buku teks atau internet. Kegiatan mengobservasi objek asli juga dilakukan peserta didik, namun semua kegiatan tersebut ternyata tidak disertai dengan tuntutan atau instruksi kepada peserta didik untuk melakukan kegiatan lanjutan berupa mengukur dan mengklasifikasikan. Hal ini menyebabkan penggunaan keterampilan mengukur dan mengklasifikasikan menjadi tidak dilakukan peserta didik. Padahal mengukur/melakukan pengukuran merupakan proses dasar dalam sain, yang seharusnya dapat menambah ketepatan pada observasi, klasifikasi dan komunikasi, serta memberi peluang kepada mereka untuk menghasilkan produk ilmu baru, seperti yang dikemukakan oleh Carin \& Sund (1989, p.6). Keberhasilan peserta didik dalam menghasilkan produk baru tentu saja tidak terjadi begitu saja, namun memerlukan proses prosedural, menggunakan segenap keterampilan proses yang dimilikinya. Penggunaan keterampilan proses yang tidak menyeluruh atau tidak seimbang diduga kuat akan mempengaruhi kemampuan peserta didik dalam menghasilkan ilmu baru. Oleh karena itu, sudah seharusnya guru melakukan usaha keras untuk mengimplementasikan PKP secara seimbang dalam pembelajaran biologi. 
Selama dilakukan penelitian ini, hanya ada seorang guru/responden (disebut sebagai responden khusus) yang menunjukkan tekad kuat untuk mengimplementasikan PKP dalam pembelajaran biologi. Dia menyatakan tidak peduli dengan materi yang banyak, dan selalu berupaya untuk membelajarkan biologi melalui praktikum (dengan mengajak peserta didik untuk menggunakan keterampilan proses sain).

...Saya tidak peduli dengan materi yang banyak, saya selalu mengupayakan praktikum untuk setiap pokok bahasan. Sebagai konsekuensinya, peserta didik perlu mempelajari sendiri materi yang mudah dipabami, sedangkan materi yang dibahas di kelas banyalah materi yang sulit, yang memerlukan kajian mendalam dengan bantuan guru...

Responden ini juga mengemukakan secara rinci tentang cara yang dilakukan untuk mengatasi kendala implementasi PKP yang ternyata ada pada peserta didik.

...Kondisi peserta didik ini menjadi kendala, karena input peserta didik di sekolab ini (pen: SMAN AE) memang cukup memprihatinkan... ...Mereka juga memiliki kemampuan komunikasi yang relatif rendah. Cukup banyak peserta didik yang pada awal masuk sekolah ini sulit berkomunikasi. Jumlah mereka mencapai lebih dari 50\%. Mereka kurang mampu menjelaskan konsep secara urut, dan pada umumnya menggunakan bahasa Jawa (bahasa tidak standar). Jadi, hal yang paling utama dan pertama harus dilakukan adalah mengajari peserta didik agar mau "ngomong" (melatih kemauan dan keberanian berbicaralberkomunikeasi).

...Hal terpenting untuk dilakukan bagi peserta didik kelas $X$ ialah membangun atan mengembangkan rasa percaya diri peserta didik, melatih disiplin, dan mengembangkan kemampuan bekerjasama. Jika kemampuan itu terbentuk, maka penerapan pembelajaran dengan menerapkan pendekatan keterampilan proses sain pun menjadi mudah. Yang sulit adalah Kalau mereka sulit ditata dan sulit berkomunikasi”.
Dari penjelasan responden tersebut, tampak jelas bahwa dalam diri seorang guru biologi perlu ada tekad yang kuat untuk dapat menerapkan pendekatan keterampilan proses secara memadai. Tekad akan mendorong seseorang untuk berupaya keras dalam rangka menghilangkan berbagai kendala, agar PKP dapat diimplementasikan dengan baik. Tekad kuat itu penulis sebut sebagai komitmen. Selain dibutuhkan tekad atau komitmen yang kuat, ditemukan sejumlah faktor pendukung bagi guru untuk dapat mengimplemantasikan PKP dalam pembelajaran biologi.

Pernyataan lain dari responden khusus ialah sebagai berikut.

...Hal/faktor yang dapat mendukung pelaksanaan pembelajaran dengan pendekatan keterampilan proses, antara lain ialah fasilitas yang dimiliki sekolah. Fasilitas yang dimiliki sekolah ini (pen: SMAN AE) antara lain ialah laboratorium, lingkungan sekitar, ICT, perpustakaan, dan lain-lain. Sejaub dapat digunakan, ya penggunaannya barus dioptimalkan. Salah satu fasilitas yang dimiliki sekolah ini ialah mikeroskop binokuler, yang jumlahnya ada dua buah...

Pada saat responden khusus ini berhalangan masuk kelas untuk menyelenggarakan pembelajaran karena tugas lain maka responden ini memilih strategi khusus sebagai solusi yang menurut peneliti sangat bagus dan patut diteladani oleh guru/ responden lain.

...Apabila pembelajaran tidak dapat dilaksanakan karena guru mendapat tugas lain, misalnya tugas yang harus dikerjakan di luar sekolah, maka guru akan mencari guru pengganti... ...Untuk menjamin bahwa pembelajaran yang saya rencanakan terlaksana seperti yang diharapkan, saya melaksanakan coaching, untuk menyampaikan pesan-pesan penting yang terdapat dalam RPP kepada guru pengganti...

Pernyataan responden khusus tersebut mencerminkan adanya pemahaman dan kesadaran yang baik pada guru biologi mengenai hakekat biologi dan hakekat pembelajaran biologi. Hal itulah yang selanjutnya 
mendorong munculnya tekad atau komitmen guru untuk menerapkan PKP dalam setiap kegiatan pembelajaran yang diselenggarakannya. Dengan demikian maka jelas bahwa adanya komitmen guru, ternyata merupakan faktor pendukung penting bagi guru untuk menerapkan PKP.

Berdasar kepada uraian tersebut diperoleh informasi bahwa implementasi PKP dalam pembelajaran biologi ternyata belum terlaksana dengan baik. Hal ini tidak akan dapat diungkap dengan baik jika dalam penelitian ini tidak digunakan metode kualitatif yang digabung dengan metode kuantitatif. Menggunakan gabungan kedua metode tersebut dapat diperoleh informasi komprehensif yang menggambarkan kualitas implementasi PKP dalam pembelajaran biologi, beserta berbagai faktor pendukung dan penghambatnya. Faktor pendukungnya ialah fasilitas yang dimiliki sekolah dan adanya komitmen yang tingggi pada guru untuk mengimplementasikan PKP dalam pembelajaran biologi. Sedangkan faktor penghambatnya beberapa hal, yaitu padatnya tugas guru, banyaknya materi biologi, adanya rasa khawatir pada sebagian besar guru dalam menghadapi UN, dan kurangnya komitmen guru untuk mengimplementasikan PKP.

\section{Simpulan dan Saran}

Simpulan

Simpulan dari penelitian ini ialah bahwa kualitas implementasi PKP dalam pembelajaran biologi yang diselenggarakan di SMA negeri kota Semarang belum mencapai kategori baik. Hal ini ditandai dengan adanya penggunaan keterampilan dasar yang terlalu dominan oleh penggunaan keterampilan dasar (terutama sekali penggunaan keterampilan komunikasi) dan maraknya praktik pembelajaran tekstual (pembelajaran berorientasi materi).

Faktor pendukung utama implementasi PKP dalam pembelajaran biologi di SMA negeri di kota Semarang adalah adanya fasilitas yang tersedia di sekolah dan komitmen guru yang tinggi untuk mengimple- mentasikan PKP. Faktor penghambatnya ialah adanya beban tugas mengajar guru yang terlalu berat, materi pelajaran biologi yang sangat banyak, kekhawatiran sebagian besar guru dalam menghadapi UN, dan kurangnya komitmen pada sebagian besar guru untuk mengimplementasikan PKP.

Saran

Beberapa saran yang perlu dikemukakan ialah sebagai berikut. (1) Guru biologi SMA di kota Semarang perlu selalu diingatkan agar tidak terlalu khawatir terhadap kesiapan peserta didik dalam menghadapi UN. (2) Guru perlu diyakinkan dan meyakini bahwa menerapkan PKP dalam pembelajaran biologi merupakan hal yang sangat penting untuk dilakukan. (3) Dalam evaluasi implementasi kurikulum perlu digunakan pendekatan mixed-method agar dapat diperoleh informasi yang komprehensif.

\section{Daftar Pustaka}

Alfiero, L., Apanovitch, C., Bearor, J., McNulty, G., Michaud, J., \& Simmonds, S. (2008). Cape elizabeth schools curricullum management plant. Towson: Baltimore County Public Schools.

Arikunto, S., \& Jabar, C. S. A. (2004). Evaluasi program pendidikan: pedoman teoretis praktis bagi praktisi pendidikan. Jakarta: PT Bumi Aksara.

Brannen, J. (2005). Memadu metode penelitian kualitatif dan kuantitatif. Cetakan ke VI. Yogyakarta: Penerbit Fakultas Tarbiyah IAIN Antasari Samarinda bekerja sama dengan Pustaka Pelajar. ISBN: 979-8581-107-9.

BSNP. (2006). Panduan penyusunan kurikulum tingkat satuan pendidikan jenjang pendidikan dasar dan menengah. Jakarta: Badan Standar Nasional Pendidikan.

Carin A.A. \& Sund R.B. (1989). Teaching science through discovery. Sixth Edition. Melbourne: Merril Publish Company.

Claeys, C., Neve, J., Tulkens, P.M., Spinewine, A. (2012). Content validity and inter-rater reliability an instru-ment to 
charachterize unintentional medication discrepancy. Original Re-search Article. Drugs Aging. Springer International Publishing, A.G., 20 (7), 577-591.

Creswell, J.W. (2008). Educational Research: Planning, conducting, and evaluating quantitative and qualitatif research. Third Edition. Pearson International Edition. New Jersey: Pearson Education Inc.

Djohar. (15 Mei 2003). Gambaran umum program pembaharuan pendidikan MIPA dan bahasa inggris. Makalah disampaikan pada Penataran Guru Penelitian di YAMB, Yogyakarta.

Setiadi, H., Ghani, A. R. A., \& Suyatno. (2006). Evaluasi pendidikan: konsep dan aplikasi. Jakarta: Uhamka Press.

Hayat, B. (2006). Prinsip-prinsip dan strategi penilaian kelas. Jakarta: Pusat Penilaian Pendidikan. Badan Penelitian dan Pengembangan. Departemen Pendidikan Nasional.

Kemendiknas. (2006a). Peraturan mendiknas no 22 tahun 2006 tentang standar isi untuk satuan pendidikan dasar dan menegah. Jakarta: Depdiknas RI.

Kemendiknas. (2006b). Peraturan mendiknas no 23 tabun 2006 tentang standar kompetensi lulusan tingkat sekolah menengah pertama dan madrasah tsanawiyah. Jakarta: Depdiknas RI.

Kemendiknas. (2007). Peraturan mendiknas no 41 tabun 2007 tentang standar proses pelaksanaan kurikulum pada jenjang pendidikan dasar dan menengah. Jakarta: Depdiknas RI.

Madaus, G.F., Scriven, M., Stufflebeam, D.L. (1986). Evaluation models: viewpoints on educational and human services evaluation. Boston: Kluwer Nijhoff Publishing.

Martin, R., Sexton, C., Franklin, T., \& Gerlovich, J. (2005). Teaching science for all children: inquiry methods for constructing understanding. New York: Pearson Education, Inc.
OECD. (2010). PISA 2009 Result: executive summary. 1-21.

Pusat Kurikulum Badan Penelitian dan Pengembangan. (2007). Naskah akademik kebijakan kurikulum mata pelajaran IPA. Jakarta: Depdiknas RI.

Smith, T. M., Desimone, L. M., Zeidner, T. L., Dun, A.C., Bhatt, M., \& Rumiyant-seva, N.L. (September 2007). Educational evaluation and policy analysis. Inquiry-oriented instruction in science: Who teachs that way? ProQuest Education Journals, 29 (3), 169199.

Steinmetz, A. (2000). The discrepancy evaluation model. evaluation models: evaluation in education and buman services. Dalam: Stufflebeam, D. L (Ed), Madaus, G.F., Kellaghan T., Evaluation models: viewpoints on educational and buman services evaluation. ISBN: 978-07923-7884-6 (Print) 978-0-306-475597 (Online), 49, 127-143.

Stufflebeam, D.L.; Madaus, G.F.; Kellaghan, T. (2002). Evaluation Models: Viewpoints on Educational and $\mathrm{Hu}-$ man Services Evaluation. Second Edition. Kluwer Academic Publishers. New York. 509 pgs.

Undang-undang Sisdiknas nomor 20 tabun 2003

Wheeler, S.L. (2012). From Discrepancy Evaluation To Response To Intervention (Rti): Are We Ready In Higher Education? Dissertation. Published by ProQuest LLC (2012). UMI 3544014. Microform Edition (C) ProQuest LLC.

Widoyoko, S. P. (2008). Peranan evaluasi program pembelajaran dalam meningkatkan kualitas pendidikan. Makalah penyerta disampaikan dalam Seminar Strategi Peningkatan Kualitas Pendidikan pada tanggal 22 Maret 2008, di PPS UNY, Yogyakarta. Kerjasama PPS UNY - HEPI.

Worthen B.R.\& Sanders J.R. (1981). Educational evaluation: theory and practice. Woshington: Charles A. Jones Publishing Company. 